\title{
Public Sector Procurement Practice: A Leadership Brainteaser in South Africa
}

\author{
Gezani Mazibuko \\ First Choice Achievers Learning Centre NPO, South Africa \\ hlohlo@lantic.net
}

\begin{abstract}
In the application of the procurement practices, public's confidence can be impacted by unethical public procurement practice as is predominant at the initial phase of tender planning procedure. Prices can be overestimated and outcome is that a missed prospect vis-à-vis finance for mega infrastructure projects. There are convolutions, proportions and an extraordinary bulk of financial stream as handy transactional dealings interacts in the market for goods and services. Certainly, procurement is mostly susceptible to unscrupulous procurement and nonconformity with relevant legislations. Such destructive practices prohibit government from procuring at cheaper prices. The paper will bridge ranks into the academic environment discourses with regards to accountability, institutional leadership capacity, transparency, stewardship, compliance and enforcement of legislation, good governance and corruption in research. The study seeks to scrutinise methods which gave rise to leadership brainteaser. A descriptive and content analysis qualitative research method will guide the study.
\end{abstract}

Keywords: Procurement practices, corruption, leadership, public sector.

\section{Introduction}

Public procurement is an intricate utility, with multidimensional procedural action relating to unrestricted policy. Public procurement starts momentous modus operandi in government and it thus stands as the bureaucratic mandatory for distribution of government amenities. Procurement can be seen as a technique structured method used to streamline and institution procurement process and achieve desired results while tradable budgets outlays, decreasing time period, building time in supplier relationships. Procurement can be unswerving, unintended, responsive or hands-on. For the purposes of this paper it is imperative to bring into context issues of best and the negative practices in government, of which the outcome or product is value for money or waste of public funds. The Auditor General of South Africa has identified sixteen national and provincial government institutions for material implementation. The outcome regarding the manoeuvre was that 28 material irregularities amounting to R2.81 billion financial losses was widespread (South Africa, Republic, 2018-19).

An amount of R2.51 billion was known, while R0.3 billion estimated amount was not known. The nature of material irregularities were poised in the unfair or uncompetitive procurement processes, overpricing of goods and services procured, supplier appointed that did not deliver goods and or payment of goods or services not received. Indeed, the report paints a gruelling picture in the history of public administration in South Africa. There is, without doubt, a shortfall of academic research to government procurement practices and the continuum of unethical procurement practices in South Africa. The public procurement misgivings warrant a research in order to augment the studies available in the public domain. However, acknowledgment to acclaimed few scholars such as Taylor \& Raga (2010), Mazibuko and Fourie (2017) and many others who deemed it fit to research on the subject, practice and concomitant riddle. The Constitution and relevant legislations are noteworthy in regulating government procurement in South Africa as they relate to procedures. The fact that government is the market regulator and partaker of legal and regulatory framework prognosis, can be regarded an orthodox.

Public Procurement Reform: Procurement is moving from transactional oversight to strategic participation within institutions with deep infiltration of technology in the front and back offices and house administration procedures. Like any government internationally, South Africa has undertaken several procurement transformation since1994, to modernise management practices, create a user friendly environment. The procurement procedure should be profound to meeting the wants of the society (Ambe \& Badenhorst-Weiss, 2012). In discussing public-sector it is incumbent to note that the public-sector institutions i.e. government departments, constitutional institutions, municipalities and entities (South Africa, Republic, 2003b; Auditors/Global, Institute of International Auditors (IIA), 2013; South Africa, Republic, 2015c; 2016). 
Corruption Perceptions Index: South Africa: Corruption perception index assist to gauge how countries are with regards to corruption. With a 2019 ranking of 70 out of 180 countries and a score of 44 out of 100 (TI, 2019), compared to the 2018 ranking of 73 out of 180 (TI, 2018) and score of 43 out of 100 (TI, 2018), South Africa has improved only marginally in terms of score and ranking, which is the real indicator of perceptions about corruption in the country. South Africa is still among those countries deemed to have serious corruption problems (TI, 2018; 2019). South Africa has steadily been performing worse from year to year (2018 and 2019). This is in terms of the Corruption Perceptions Index (CPI), which ranks countries/territories based on how corrupt a country's public sector perceived to be. This state of affairs could prove damaging to the country's reputation (Institute of Risk Management of South Africa (IRMSA), 2015).

Legislative Framework: The procurement procedure underpinned by procurement legislation (South Africa, Republic, 2000) is important in the procurement environment. Such a legislative regimen was established by parliament to reflect the constitutional status in terms of section 217. The government is continuing with reforms creativities in the procurement environment. The legislation applies to institutions (department, constitutional institution, a municipality or a municipal entity, public) in South Africa. The leadership should heed the fact that an institution must conduct procurement accompanied by properly planned procedures. In the legislation, the procurement contracts perse should promote categories of persons or businesses or a sector; goods that are manufactured in the country. In addition the procurement legislation is there to promote local technology and its commercialisation and the creation of jobs or intensification of labour absorption. Enterprises based in townships, rural or underdeveloped areas, province or municipality providing goods, services or infrastructure are promoted in the legislation.

The leadership should also take into account measures regarding the involvement of a manufacturer of goods in bidding processes. Such manufactures should be those aimed at advancing industrial development and at advancing small medium and micro enterprises in high value procurement (South Africa, Republic, 2000c; 2003a; Dlamini \& Ambe, 2012; South Africa, Republic, 2020b). Treasury norms and standards have been entrenched in the legislation to ensure supplies of works (South Africa, Republic, 2003c; Arrowsmith \& Quinot, 2013). Further, there are also international regulations that guide public procurement supplies. Those regulations are the Model Law (1994 UNCITRAL Model law) (World Trade Organisation, 1994; World Trade Organisation, 2011a; South Africa, Republic, 2000a; 2004). The legislations and regulations (Quinot, 2014; South Africa, Republic, 2015c; Fourie, 2015) are intended to be fit for purpose in the application of procurement procedures. Despite the stipulation in the Constitution, the public sector leadership is still poked with unethical procurement practices and visionary leadership deficiency.

\section{Literature Review}

Conceptualisation of Procurement Practice: The bidding procedure in heralded by on getting through valuation of requirements and specification regarding the feasibility of available market demand for goods, services and works. The draft Public Procurement Bill (2020b) was designed with specific, objects in mind such as to ensure that the government institutions utilise and leverages procurement for the advancement of. In addition the instrument should stimulate an investment in the country. Leadership should acknowledge that the novel legislation is an attempt to improve the procurement procedures in government. Such transformation and reforms will give the office of the chief procurement officer certain powers and functions such as administering national legislation, ensure policies and legislations implementation and sanction compliance with national supply chain management and procurement policies, regulations, instructions and guidelines.

A bid can be rejected in case the bid is non-responsive and evidence of collusion is reported. Leadership should there exercise due consideration and provide effective and efficient leadership. Notwithstanding these rationalisation and transformation leadership has to put more effort to effectiveness in procurement procedure and rid out unethical conducts and scourge of corruption in public procurement. A provincial treasury may consult with the national treasury and facilitate the procurement of transversal term contract for goods, services or infrastructure. The relevant treasury must ensure that the institution affected by term contract appoint representatives with the mandatory proficiency to serve on the important procurement 
committee. Leadership should ensure that after goods, services or infrastructure have been procured through a transversal tenure contract, an institution must ensure that, where appropriate, a service level agreement is entered into between the supplier and the institution before any goods or services could be ordered in relations to the contract.

Procurement Procedures: Procurement procedures relate to the provision of guidance to institutions and public officials responsible for public procurement, financial management, suppliers, auditors and other persons involved in procurement. The procurement procedure is catalysed by the Constitution and relevant legislation in government. The open procedure is a single stage process whereby a contracting authority advertises the contract opportunity and then issues tender documents tender documents, including the specification and contract, to all economic operators that request to participate. The restricted procedure is a two stage process, whereby the contracting authority advertises the contract opportunity and then the economic operators submit requests to participate and then provide selection stage or pre-qualification information, which is used to perform the contract and to select the economic operators that are to be invited to tender. The contracting authority limits the number of economic operators that it invites to tender and draw up a shortlist of suppliers. A competitive dialogue procedure uses a two stage process whereby the contracting authority advertises the contract opportunity, and after submitting requests to participate the economic operators first submit pre-qualification selection stage information.

Which is used by the contracting authority to establish whether the economic operators that are qualified to perform the contract and to select the economic operators that are to be invited to tender? The last procedure is a negotiated procedure with prior publication of notice is a two stage process. In procedure, the contracting authority advertises the contract opportunity, and the economic operator s first submit pre-qualification and selection stage information, which is used by the contracting authority to establish whether the economic operators are qualified to perform the contract and to select the economic operators that are to be invited to tender. The contract authority can limit the number of economic operators to be invited to tender (Sigma, 2011; South Africa, Republic; 2012; 2015; 2015c). World best practice bench marks were needed at all times. (South Africa, Republic, 2017b). Government leadership should view public infrastructure as economic and strategic imperative in nature. Public infrastructure, particularly that relating to roads, energy, water and transport, enables the economy to grow faster and become more productive through contributing to raising competitiveness, exports and lowering the cost of doing business (South Africa, Republic, 2018). Infrastructure creates jobs for low-skilled people and promotes spatial inclusivity.

Investment in infrastructure also provides opportunities for broad based black economic empowerment (BBBEE). If infrastructure is not planned and delivered efficiently and effectively, it can retard rather than accelerate the achievement of the socio-economic and growth objectives. As a public sector manager and leadership, one would not be happy when budgets are partly spent at the end of the financial year. Under spending occurred, on average, over the 2015/16, 2016/17 and 2017/18 financial years whereby stateowned enterprises and public entities have spent not more than 75 percent and 65 percent of their respective budgeted amounts. It is demoralizing to note that, the state as a whole did not have capacity to spend more than 85 percent of the available budget. The under-spending over this period increased during a time when National Treasury Supply Chain Management (SCM) instructions became applicable to major public entities, national and provincial business enterprises. In the 2017/18 financial year, metropolitan councils had difficulties spending their capital budgets. None of the metropolitan councils spent more than 80 percent of their capital budgets. Their spending ranged between 55 to 78 percent. This was a decline from the performance of the 2016/17 financial year. In the 2017 /18 financial year the spending was recorded as follows.

30 (or 12 percent) of the municipalities spent less than 40 percent of their capital budgets; while 51 spent between 40 percent and 60 percent respectively. On one hand 94 councils spent between 60 percent and 80 percent respectively. While 53 councils spent between 80 percent of their capital budgets (South Africa, Republic, 2019b). In addition, 24 municipalities overspent their capital budgets between 100 percent and 150 percent, while 5 overspent by more than 200 percent (South Africa, Republic, 2020a). The state of affairs should be fear-provoking to the local government leadership and governance as a whole. The Construction Industry Development Board (CIDB) in the Construction Monitor-Supply and Demand (South Africa, Republic, 
2019a) posits another picture for local government. The publication perse argues that at the end of the 2017/18 municipal financial year, the total under spending of municipalities decreased from around R15 billion for the 2016/17 financial year to around R13 billion with metropolitan councils contributing around R11 billion to under spending. In the 2017/18 financial year, metropolitan councils had difficulties spending their capital budgets. The CIDB monitor also pointed out that in the 2017 /18 financial year 226 (or 88 percent) of municipalities spent less than 100 percent of their capital budgets, a figure which is approximately the same as in the $2016 / 17$ financial year.

Certainly, leadership should view this as an overwhelming and gruelling state of affairs in the current local governance. Public procurement practices riddle public sector leadership. For example, the trends in high profile public sector mega projects such as the Gauteng Improvement Project, the Gautrain Rapid Rail Link System, the Ingula Pumped Storage Scheme, the King Shaka International Airport, the New Multi-Product Pipeline and the Kusile and Medupi coal power plants revealed an order of magnitude increase from the initial estimated projects cost to the final costs with a concomitant increase in schedule for completion. The time and cost-over-runs on the Kusile and Medupi coal power plants provide an indication of the degree to which mismanaged mega projects can damage the economy. Certainly, the leadership in the public sector spends sleepless nights, arduous and are riddled by the procurement practices.

Bidding Processes: Procurement phase encompass the necessity documentation, obtaining of goods preparation, request dispensation, and determination of procurement method, planning and publication for offer to tender, bid proposal meeting and site visits. The cycle does not end there; there are also milestones such as submissions and opening, bid offer valuation, award approvals, deal intercession, contract award and management. All these ingredients have to go into the basket of what the procuring institutions have to follow succinctly and comply with polices and legislations. The leadership in the procurement environment should make sure that an institution must prepare an invitation to bid, inviting bidders to submit bids for the provision of goods or services. Such arrangement must exclude consultancy services or infrastructure. Appropriate standards and bid documents must contain clear instructions, description of the object of procurement, methodology, criteria and proposed form and conditions of contract. The bidding process comprise elements such as invitation to bid, bid documents, qualification criteria for bidders, submission of bids, bid security deadline for the submission of bids and withdrawal modification of bids. In addition, the process have bid validity period, opening of bids, examination and evaluation of bids, rejection of bid or proposal, re-advertising of bid, verification of bidders or suppliers and award of procurement contracts (South Africa, Republic, 2020b).

The planning stage is paramount within the bidding processes. The South African pre-bidding stage relates to valuation of requirements and budgets, bid specifications, compilation of bid documents and public notice, and supplier database registration (UNODC, 2013). The planning focuses on demand, item and specification management, and supplier management as key phases in the loop (South Africa, Republic, and 2015c). The requirements of the institution's (South Africa, Republic, 2003b; 2012) market research for planning is central in orchestrating the value for money principles (South Africa, Republic, 2004; Van Weele, 2010; Crandall, Crandall and Chen, 2015; South Africa, Republic, 2015c). A single tender portal and central data base is used in South Africa. Procuring authorities use e procurement when procuring goods, services and works (Davey \& Gatenby, 2016; UNOPS, 2011; South Africa, Republic, 2004). Advertisement of tenders should be done through the Central Supplier Data Base (CSD) and comply with the (South Africa, Republic, 2016). It is worth mentioning that it is compulsory to procure goods and services through the CSD. e. Procurement which is the use of information and communication technology can increase transparency and facilitate access to public tenders (OECD, 2016). Evaluation and awarding of bid is fundamental for the leadership to be vigilant about as anything is erroneous can amount to prejudiced practice.

Leadership should ensure that information is requested from the bidders for clarification. The evaluation of tenders is underpinned by value add and procedural affair for the different range of procurement processes (South Africa, Republic, 2012). The procurement leadership should note that the procedure allows procuring authorities to cultivate conditions with regards to good, services, and public works. Valuation requirements should precede the implementation of procurement through effective and efficient procurement procedure. The basis for bid evaluation and selection are delineated in the directives to dealers and/or in the conditions 
of contract (South Africa, Republic, 2004; 2015b). With regards to the enforcement of administrative action, leadership should be cautious when dealing with contracts during the award stage to avoid astonishing circumstances. All bid documentation must include the evaluation and adjudication criteria. Tenders may be evaluated only on the basis of the pre-disclosed requirements and criteria (Bolton, 2006; Ambe \& Badenhorst-Weiss, 2012; UNODC, 2013; South Africa, Republic, 2015c; 2016; 2017a). A bid can be rejected in case the bid is non-responsive and evidence of collusion is assumed. Leadership should be upfront in terms of taking decisive decisions by cancelling procurement in the event that significant change in technical specification, no responsive bids received, insufficient bids received, irregularity in the process and evidence of corruption (Majila, Taylor \& Raga, 2014)) is widespread.

In addition, procurement can be cancelled owing to the consideration in the interest of national security (South Africa, Republic, 2017b; 2020b). Skirmish interest should be addressed in the procurement environment. If an official or close relative, associate of an official, has, or intend to acquire, a direct or indirect personal interest a matter requiring the institution's decision, that official must disclose such interest immediately after receiving the agenda of the meeting of the procurement structure of that institution. The staff of an institution may not participate in the considerations process (South Africa, Republic, 2003a; 2015c; Davey \& Gatenby, 2016). The leadership must be mindful of the persons who are prohibited from partaking in the offering processes. A bidder subject to a barring order, a minister of government department or municipal councillor, an employee of any government institution by advantage of their involvement in an unit providing or executing goods services, must be debarred from partaking in procurement process. Contract performance management give a response whether projects are effectively and efficiently performing or not. Contract lifespan controlling relates to methodical and well-organized management as a post tender process addresses performance thereof. (UNODC, 2013; South Africa, Republic, 2012; 2015; 2015c).The leadership should be wiry on the application of procedure that seek ethical procurement practices by suppliers (South Africa, Republic, 2000b; South Africa, Republic, 2017b; Raga, Bayat \& Ferrera, 2012).

\section{Methodology}

The qualitative research method was used applied for this research. Data so collected was available from previous reports on public procurement, procedure manuals, and annual reports. In addition such instruments were sourced from National Planning Commission. A wide range of publications and journal articles, and web-based Internet were also collected.

\section{Results and Discussion}

The legislative instruments, institutional parameters, procedures, are the pillars practice whether private sectors. The South African public sector uses bidding processes namely; planning stage, evaluation and awarding of bids. The outlooks of the processes are similar to the ones applied internationally. However, there are some gaps as can be discernable from the discussion which warrant a drastic model to turn around conundrums. Despite all legislative and other institutional arrangements, the public sector procurement practices still face the leadership mystery and teasing. To this end, falling public sector budgets and increasing under-spending over time are pervasive in the procurement environments. At the same time, the effectiveness of interventions to improve government's inability and incapacity to spend its infrastructure budget remains questionable and ruptured.

Institutional Arrangements: The institutions must conduct procurement, plan, and document requirements, obtain authorisation, define procurement requirements, identify appropriate standards bids documents, provide procurement information, and communicate with all bidders. Leadership has massive role to play in ensuring the integrity of national, provincial, municipalities and entities. Institutions must conduct procurement in accordance to proper planning and document requirement authorisation, procurement needs, standard bid document, methodology and criteria to evaluate bids and communicate such to bidders in a confidential manner. Procuring institutions have and thus take such matters regarding, specification set criteria perse. Government continues to rationalise and transform procurement legislations. Provincial treasuries must exercise control over the implementation and enforce transparency and effective management of procurement function. Leadership must ensure that the issues of integrity, development of 
measures, and review of institutional decisions, monitoring and guidance on procurement system, database creation and use of technology renowned (South Africa, Republic, 2020b). A degree of integrity is needed from the procurement official point of view.

Delivery Management: South Africa's public infrastructure investments over the past two decades amount to R3 trillion. Despite this massive budget, the speed, quality and efficiency of many of these projects have not matched the level of investment. Project planning at all levels, including for long-term maintenance is proved to inadequate (South Africa, Republic, 2019c). The major contributor to disappointing procurement environments resides in the absences of delivery management and the critical leadership role played by a knowledgeable servants in terms of planning, specifying, procuring and delivering infrastructure projects efficiently and effectively, resulting in value for money. Certainly, poor planning in terms of other aspects in the chain may results in defects in the identification, assessment and preparation of the project.

Surely, procurement officials must amongst others, perform duties fit for purpose, constituent to situations. Above all, poor structuring and workmanship, unfulfilled management of the tender process, noneresponsiveness in contract management and sloppy draft contracts can be enormousness. Surely, leadership in government and particular procurement environments must be vexed about the trend with regards to delays in infrastructure development. The issue is aggravated by deficiency in management capacity and proper skills. An innumerable of uprightness hazards is rampant in any unrestricted procurement cycle as risk occurs at every step of the method (OECD, 2016). Irregularities in the procurement processes and inadequate contract management took place on school, housing and water infrastructure projects. Projects displayed weaknesses with regards to delayed delivery, poor quality work, waste and mismanagement. Certainly, the delays were due to inadequate planning and project management processes, prolonged procurement processes and poor contractor performance.

For example, unfair or uncompetitive procurement processes resulting in overpricing of goods and services were committed by 11 or 39 percent of departments with a value of R438 million and that resulted in irregular procurement. In some instances suppliers did not deliver goods after appointment and it occurred to 1 or 4 percent of departments and the value was R2 200 million. Payment of goods or services not delivered occurred in 11 or 39 percent of departments and the amount to that effect equals to R55 million. Poor workmanship also resulted in payment for poor quality experienced at 2 or 7 percent of departments with a value of R7, 6 million. Invoices or claims were not paid on time whereby 3 or 11 percent of departments were culprits to the value of R106 million was delayed. To this end, overall internal control slightly regressed (South Africa, republic, 2018-19). Accountability for government spending, impact of poor financial and performance management such as the delivery of key government programmes is paramount. To this end, the widespread deficiency of consequences made the situation even worse.

Remedies and Enforcement: Procuring authorities should have in the procedure remedy of damages for aggrieved parties as an instrument to resolve dispute. The tool should be used in the interest of parties, i.e. the authority and supplier. The instrument would be used to attempt to resolve the conflict before taking it to courts. To this end, there are no specific review authorities that review claims regarding non-compliance save with the stipulation of the regulator in the envisaged Procurement legislation (2020b). However, National Treasury, Auditor General, Special Investigating Unit, Public Protector and to some extent the Human Rights Commission can investigate claims and assist claimants to resolve such conflicts. Arguably, the contracts awarded in terms of procurement legislation do amount to administrative action. To this end, the PAJA has wide-ranging vertical procedures and effectively allows any person to instituted proceedings before the high courts for the review regarding such administrative actions. It is generally incumbent upon the leadership and in particular within the procurement environment to ensure that the prescript of the Constitution, procurement legislation, relevant guides and regulations are practiced wholly. Leadership should vigorously; snoop that regulations are applicable to all contracts implemented by institutions relating to acquisition, disposal of assets and letting and hiring of assets inclusive of public private partnerships.

Capacity Building: The government budgets huge amount of money for capacity building and yet procurement staff are still faced with challenges in the procurement environment. Such riddles relate to continuous poor policy implementation and operational flaws in supply chain management. Institutions overspend budgets; if they don't overspend they underspend the budget which is as it was exposed in this 
paper. The remedies should be applied in terms of PAJA requirements which stipulate that institutions should have measures to address conflicts and complaints regarding procurement claims procedures. How well the procurement procedure is implemented will depend on the scope of training provided in the procuring authorities. Such can be achieved by enforcing code of conducts for officials. Procurement authorities should develop; strengthen skills, abilities and processes and resources within the procurement environments (DeCorby-Watson et al., 2018).

\section{Conclusion and Recommendations}

The public sector procurement procedure is a manifold procedures such as open restricted procedure, competitive and negotiated procedures. The professionalism and ethics, contract performance management, accountability and leadership, and reduce tolerance on corruption will serve as a recommendation for this study:

Professionalism and Ethics: It is imperative that leadership should value professionalism in the procurement environments. Officials in the procurement environment abide by the official code of conduct such as not to follow suppliers during the bid phase, suppliers should receive identical information during the solicitation phase, specification should be linked to function and to performance, individuals having a personal or financial interest with suppliers should be prohibited from any involvement. The occurrence of conflict of interest can arise when the procurement personnel's private interest such as outside professional relationships or personal financial assets interfere or appear to interfere with the proper performance of his or her professional functions or obligations. As such within the procurement environment, conflict of interest may arise in connection thereto. There is a need for development of professional cadre of procurement officials through the creation of certification of suitably qualified officials.

Contract Management Performance: Contract management performance is an area where improvement has to be continuously made. In terms of the oversight contract management, all contractual obligations should be settled and monies owing are paid within reasonable terms. However, in South Africa the policy will state that a supplier will be paid within 30 days and those 30 days will turn into months and years without the institutions or contracting authority having paid the supplier on time. Internal Audit and Risk Management units should conduct audits. The contract management have to safeguard the day to day procurement accomplishments follow the essence of and segments of the contract.

Accountability and Leadership: Accountability is essential to preserve faith in the integrity of procurement system and market transparency. The need to develop, nurture capacity and capability in the procurement environment cannot be overemphasized. The procurement risk and performance should be managed through strong management and internal control. Good supremacy can also be accomplished by exercising limpidity; timeous reporting and auditing that will deliver effective accountability. Governance which is fit for purpose is supreme in the procurement environment. Oversight and control is necessary as it support answerability and augment truthfulness. It aids to engender valued substantiation on the performance and effectiveness.

Reduce Tolerance on Corruption: Use data analytics to reduce corrupt activities in public procurement. The data analytics can assist institutions to inspect, transforming and modelling data with an aim of discovering critical and useful information. Such information can help institutions to arrive at a conclusion and supporting decision-making.

\section{References}

Ambe, I. M. \& Badenhorst-Weiss, J. A. (2012). Procurement challenges in the South African public sector. Journal of Transport and Supply Chain Management, 6(44), 242-261.

Arrowsmith, S. \& Quinot, G. (2013). Public procurement regulation in Africa. Cambridge (UK): Cambridge University Press.

Auditors/Global, Institute of International Auditors (IIA). (2011). Supplemental guidance: Public sector definition. Altemonte Springs (FL): Global Headquarters of Institute of InternationalAuditors. 
Bolton, P. (2006). Government procurement as a policy tool in South Africa. Journal of Public Procurement, 6(3), 193-217.

Bolton, P. (2008). The public procurement system in South Africa: Main characteristics. Public Contract Law Journal, 37(4), 781-802.

Bolton, P. (2016). Public procurement as a tool to drive innovation in South Africa, Potchefstroom electronic Law Journal/Potchefstroomse electroniese Regsblad, 19(1), 1-35.

CIPS (Chartered Institute of Purchasing \& Supply - Austrialia. (2007). Contract management guide. Melbourne (AU): CIPS Australia.

Crandall, R. E., Crandall, W. R. \& Chen, C. C. (2015). Series on Ressources Management. Principles of supply chain management.Second Edition New York (NY): CRC Press/Taylor \& Francis Group.

Davey, J. \& Gatenby, A. (2016). The government procurement review. 4th ed. London (UK): Law Business Research. Ilkeston.Derbyshire:Encompass Printing Solutions (UK).

DeCorby-Watson, et al. (2018). Effectiveness of Capacity building interventions relevant to public health practices: a systematic review. Toronto: BMC Public Health.

Dlamini, W. M. \& Ambe, I. M. (2012). The influence of public procurement policies on the implementation of procurement best practices in South African universities. Journal of Transport and Supply Chain Management, 6(1), 277-293.

Fourie, D. J. (2015). Procurement in the South African public service: A reflection of the ethical and legislative fraework. Public and Municipal Finance, 4(2), 38-45.

Institute of Risk Management South Africa (IRMSA). (2015). IRMSA risk report: South African risks 2015. 1st ed. Sandton (ZA): IRMSA.

Junior, S. (2015). Nurturing domestic firms through public procurement: A comparison between Brazil and Japan. Public Policy and Administration, 31(1), 29-50.

Kabega, C., Kule, J. W. \& Mbera, Z. R. (2016). Effect of procurement practices on performing of public projects in Rwanda: A case study of Bugesera district office construction project. International Journal of Economics, Commerce and Management, United Kingdom, IV(5), 377-396.

Majila, T., Taylor, J. D. \& Raga, K. (2014). A comparative analysis of anti-corruption legislation and anticorruption agencies in the Eastern Cape and Northern Provinces: Journal for Transdiscilinary Research in Southern Africa, 10(1), 219-240.

Mazibuko, G. \& Fourie, D. J. (2017). Manifestation of unethical procurement practices in the South African public sector. African Consortium of Public Adminstration (ACPA), 9(9), 106-117.

Mentzer, J. (2007). Handbook of global supply chain management. Thousand Oaks (CA): SAGE Publications.

OECD. (2016). Preventing Corruption in Public Procurement. Paris: OECD.

Quinot, G. (2014). An institutional legal structure for regulating public procurement in South Africa: Research report on the feasibility of specific legislation for National Treasury's newly established. Pretoria (ZA): National Treasury.

Raga, K., Bayat, M. S. \& Ferrera, N. (2012). Nature and extent of procurement management relationships between the provincial governement of Eastern Cape and the Building Industry. Kuwait Chapter of Arabian Journal of Buainess and Management Review, 1(7), 1-100.

Sigma. (2011). Public procurement. What are the public procurement procedures and when can be they used. Brief 10. January 2011. www.sigmaweb.org.

South Africa, Republic. (1996). Consitution of the Republic of South Africa Act, 1996 (Act 108 of 1996). Pretoria (ZA): Government Printer.

South Africa, Republic. (1999). Public Finance Management Act, 1999 (Act 1 of 1999) (PFMA). . Pretoria (ZA): Government Printer.

South Africa, Republic. (2000a). Promotion of Access to Information Act, 2000 (Act 2 of 2000) (PAIA) Pretoria (ZA): Government Printer.

South Africa, Republic. (2000b). Promotion of the Administration of Justice Act, 2000 (Act 3 of 2000) (PAJA) Pretoria (ZA): Government Printer.

South Africa, Republic. (2000c). Preferential Procurement Policy Framework Act, 2000 (Act 5 of 2000) (PPPFA). Pretoria (ZA): Government Printer.

South Africa, Republic. (2003a). Broad-Based Black Economic Empowerment Act, 2003 (Act 53 of 2003) (BBBEEA). Pretoria (ZA): Government Printer.

South Africa, Republic. (2003b). Policy strategy to guide uniformity in procurement reform processes in government. Pretoria (ZA): National Treasury. 
South Africa, Republic. (2003c). Municipal Finance Management Act, (Act 56 of 2003) (MFMA) Pretoria (ZA): National Treasury.

South Africa, Republic. (2004). Supply chain management: A guide for accounting officers/authorities. Pretoria (ZA): National Treasury.

South Africa, Republic. (2012). Western Cape Provincial Treasury Instructions: Chapter 16A-Supply Chain Management: Goods and service. Cape Town, ZA: Western Cape Provincial Treasury.

South Africa, Republic. (2015). Standard for uniformity in construction procurement. Pretoria (ZA): Government Printer.

South Africa, Republic. (2015a). South African National Accreditation System: SANS 10845-1. Construction procurement Part 1: Process, methods and procedures. Pretoria (ZA): National Treasury.

South Africa, Republic. (2015b). Construction Industry Development Board (CIDB). Standard for uniformity in construction procurement. Pretoria (ZA): Government Printer.

South Africa, Republic. (2015c). 2015 Public sector supply chain management review. Pretoria (ZA): National Treasury.

South Africa, Republic. (2016). SCM review update 2016. Pretoria (ZA): National Treasury.

South Africa, Republic. (2017a). Capital planning guidelines. Pretoria (ZA): National Treasury.

South Africa, Republic. (2017b). National Treasury audited consolidated financial statements. Pretoria: National Treasury.

South Africa, Republic. (2018). Industrial Policy Action Plan 2018/19-2020/21, Economic Sectors, employment and infrastrure development cluster. Pretoria: Department of Trade and Industry.

South Africa, Republic. (2018-19). Consolidated General Report on National and Provincial audit outcomes. PFMA 2018-19. Pretoria: Auditor General of south Africa.

South Africa, Republic. (2019a). The Construction Industry Development Board (CIDB) in the Construction Monitor - Supply and Demand. Johannesburg: CIDB.

South Africa, Republic. (2019b). State of Local Government Finance: Section 71 quarter 4 local government results as at 30 June 2019. Pretoria: National Treasury.

South Africa, Republic. (2019c). Budget Review 2019. Pretoria: National Treasury.

South Africa, Republic. (2020a). Public infrastructure delivery and construction sector dynamism in the South African economy. Pretoria (ZA): Presidency.

South Africa, Republic. (2020b). Draft Public Procurement Bill. Pretoria: National Treasury.

Taylor, J. D. \& Raga, K. (2010). Preferential procurement: A case Study of South Africa. Working Paper, 13, 6.

UNODC. (2013). Transparency, objectivity and competition in public procurement. Legal assessment of Mexico's compliance with Article 9 of the United Nations. Convention Against Corruption (UNCAC) in the Federal Gove. New York: UNODC.

UNOPS. (2011). Transparency and public procurement. Supplement to the 2011 annual statistical report on United Nations procurement. UNOPS and United Nations Global Marketplace (UNGM). New York: UNOPS.

Van Weele, A. (2010). Purchasing and supply chain management: Analysis, strategy, planning and practice. 5th ed. Hampshire: CENGAGE Learning.

World Bank. (2016). Benchmarking public procurement 2016: Assessing public procurement systems in 77 countries. Washington, DC: World Bank Group.

World Trade Organisation (WTO). (1994). WTO GPA and the UNCITRAL Model Law on Procurement of Goods, Construction and Services (1994). Geneva: WTO.

World Trade Organisation (WTO). (2011a). Government procurement agreement. Geneva (CH): WTO Publications. Geneva: WTO.

World Trade Organisation (WTO). (2011b). UNCITRAL: Model law on public procurement World Trade Organisation (WTO). Geneva: WTO. 